UDC 811.111-26

DOI https://doi.org/10.24919/2308-4863/40-2-23

Olga OCHERETNA,

orcid.org/0000-0001-7077-4878

PhD in Pedagogy, Associate Professor,

Associate Professor at the English Language Department № 2

National University "Odesa Maritime Academy"

(Odesa,Ukraine) ocheretolya5@gmail.com

Uliana SHOSTAK,

orcid.org/0000-0002-3258-2098

PhD in Psychology,

Senior Lecturer at the Foreign Philology and Translation Department

Vinnytsia Institute of Trade and Economics

of Kyiv National University of Trade and Economics

(Vinnytsia, Ukraine) ulyana.shostak30@gmail.com

\title{
GENDER PECULIARITIES OF ADDRESS IN ENGLISH
}

The research aims to identify and characterize the origins of the notion of "gender", to make a general description of "gender", to characterize gender studies in linguistics, to trace and to analyze the gender aspect of the use of address in English. The object of research is gender aspect of the use of address in English. Address-regulations are evaluative in nature and regulate the relationship between interlocutors in accordance with the speech, etiquette standards and norms common in a particular society. The address without syntactic connections with other words in the sentence has a special intonation and a special communicative purpose - to control the behavior of the recipient. An address creates a transition between identifying and predicative nominations, from objective semantics to subjective semantics. Depending on the gender characteristics of the participants of communication, the situation of communication and the intention of the addressee in the messages are dominated by elements of encouraging, contact, meta communicative or evaluativemodal speech actions. When choosing an address in a particular speech act, the characteristics of the addressee are differentiated at the basic level of categorization: acquaintance-stranger, man-woman, senior-junior-equal, socially higher-lower-equal, and so on. In the etiquette of business communication, this differentiation usually has clear linguistic equivalents. Gender features of the use of address in English include address-nominations proper names, nicknames; official circulating constructions related to generally accepted norms in society; treatment without mentioning the addressee; terms of kinship in the literal and figurative sense; age, sex; profession; status and role characteristics; evaluative address of personality characteristics; substantivized adjectives; metaphorical.

Key words: address, gender, communication, female, male, speech act.

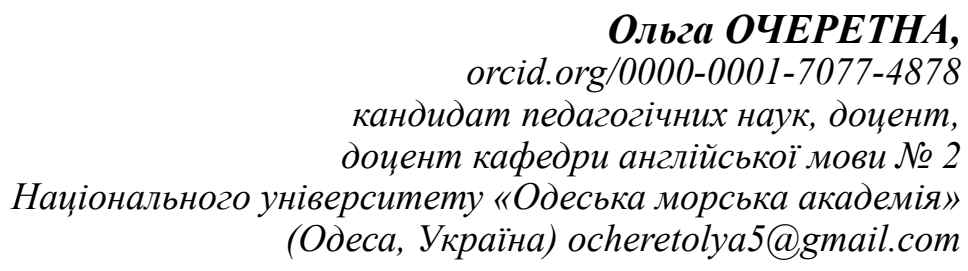

Уляна ШОСТАК, orcid.org/0000-0002-3258-2098 кандидат психологічних наук, старший викладач кафедри іноземної філології та перекладу

Вінницького торговельно-економічного інституту

Київського начіонального торговельно-економічного університету (Вінниия, Україна) ulyana.shostak30@gmail.com

\section{ГЕНДЕРНІ ОСОБЛИВОСТІ ВЖИВАННЯ ЗВЕРТАНЬ В АНГЛІЙСЬКІЙ МОВІ}

Дослідження має на меті виокремити та охарактеризувати витоки поняття «гендер», здійснити загальну характеристику поняття «гендер», охарактеризувати гендерні дослідження у лінгвістиці, прослідкувати та здійснити аналіз гендерного аспекту вживання звертань в англійській мові. Предметом дослідження є гендерний 
аспект вживання звертань в англійській мові. Звертання-регулятиви мають оцінний характер і регулюють взаємини між співрозмовниками відповідно до мовленнєво-етикетних стандартів $і$ норм, узвичаєних у певному суспільстві. Не вступаючи в синтаксичні зв'язки з іншими словами в реченні, звертання має особливу інтонаційну оформленість і особливе комунікативне призначення - управління поведінкою адресата. Звертання створюють перехід між ідентифікуючою та предикативною номіначіями, перехід від об'єктивної семантики до семантики суб'єктивного типу. Залежно від гендерних характеристик учасників комунікації ситуації спілкування та наміру адресанта у зверненнях домінують елементи заохочувальних, контактивних, метакомунікативних або оцінномодальних мовленнєвих дій. Під час вибору звертання в конкретному мовленнєвому акті відбувається диферениіачія ознак адресата на базовому рівні категоризаиії: знайомий-незнайомий, чоловік-жінка, стариий-молодшийрівний, соціально вище-нижче-дорівнює тощцо. В етикеті ділового спілкування ияя диференціація, як правило, має чіткі мовні відповідники. Гендерні особливості використання звертань в англійській мові включають звертанняномінації, власні імена, прізвиська; офіційні звертальні конструкиії, пов 'язані із загально прийнятими у суспільстві нормами; звертання без згадки адресата; терміни спорідненості у прямому та в переносному значенні; вік, стать; професія; статусно-рольові характеристики; оцінні звертання характеристики особистості; субстантивовані прикметники; метафоричні.

Ключові слова: звертання, гендер, комунікація, чоловічий, жіночий, комунікативний акт.

Problem under consideration. Genderology is one of the sciences that has appeared relatively recently and focuses on the cognition. It examines the relationship between a person's biological sex and their cultural identity, social status, mental characteristics and behaviour, including speech. Today, gender studies are reflected as a scientific field in the United States and Western Europe. In recent decades, the gender dimension has become increasingly important in assessing the processes of social functioning and development. Until recently, the issue of defining gender categories was on the periphery of public consciousness, perceived more often as a secondary social and psychological factor.

Focusing on the communicative function of a language, the study of the human factor in a language and speech, it should be noted that this contributes to the growth of scientific interest in identifying the specifics of female communicative behaviour. This interest is precisely the nature of the use of address, the property of which is the focus on the interlocutor. Despite sufficient coverage in linguistics, the issue of gender-based choice of gender forms of address representing in English personal speech remains controversial to this day. There is an urgent need to create a theoretical basis and methodological foundation for the study of gender, which would be aimed not only at the theory of linguistics but also at the theory of translation, where gender specificity has not been taken into account so far.

The latest research analysis. The scientific bibliography devoted to gender issues in various fields includes dozens of works, which may indicate the diversity of approaches to the study of this concept and the multidimensionality of its definitions.

Unlike gender, it should not be interpreted as a biological structure. Gender is a cultural mask, a social representation, rather than a natural property (Байбурин, 1985). In the trends of modern science, we see that the term 'sex' is used to denote the anatomical and physiological features between men and women. That is why J. Scott, a well-known researcher in the history of feminism, calls gender a 'social article' (Scott, 1996).

One of the first recorded cases of the use of this term was noticed in 1955 by psychologist John Money (Money, 1955). In his understanding, the concept of gender and gender role was used as characteristics that determine what a person feels by their status or behaviour, the scientist did not limit his vision of the definition (Ehrhardt, 2007). The year 1968 also played a particularly important role in the history of gender studies, the American psychologist and psychoanalyst Robert Stoller introduced the concept of 'gender' into the scientific space, when he used it in the published article Sex and Gender: on the Development of Masculinity and Femininity" (Stoller, 1968). He suggested using gender as a separate term to denote the social, behavioral, and cultural aspects of gender. Thus, there was a need to distinguish biological characteristics from those given to man through the prism of social ideas about gender, subjectively fixed in the culture of knowledge about them.

Although gender is not a linguistic category (except for socio- and, in part, psycholinguistics), analysis of language structure provides information on the role of gender in culture, what behavioral norms for men and women are fixed in different types of texts, how the perception of gender norms, masculinity and femininity changes over time, what stylistic features can be attributed to predominantly female or predominantly male, how masculinity and femininity are perceived in different languages and cultures, how gender influences language acquisition, with what fragments and thematic spheres of the linguistic picture of the world it is connected.

The linguistic tools of gender studies appear in two guises, which can be conditionally classified as follows: 
1) a language is a tool of gender cognition as an independent interdisciplinary paradigm, as a kind of intrigue of cognition, according to Iryna Khaleeva, with the appropriate branch - linguistic genderology;

2) gender-oriented linguistic research is the production of additional knowledge about language and communication, i.e, gender linguistics (Khaleeva, 2000: 10).

Linguistic gender research began in the 1990s, as did most gender research in Ukraine. Fundamental works of such foreign researchers as S. Gauthier, O. Goshchylo, S. Gubar, E. Gross, L. Irigirei, K. Kelly, Y. Kristeva, T. de Lauretis played an important role in the formation of gender linguists in Ukraine.

The aim of the article is to clarify the origins of the notion 'gender' and its features, as well as to identify the peculiarities of gender research in literary studies and to identify the gender aspect of the use of address in English.

The main body of the article. The impetus for the formation of gender linguistics was the discovery of the 'gender dimension' as 'the universal significance of human gender in all spheres of its socio-cultural existence' (Brandt, 2006: 5). Until the twentieth century, the study of gender-based creativity was irrelevant, as precedents of female authorship were perceived either as an exception or with the presumption of inferiority, while literary discourse presented by men was regarded as universal, which removed the need to study the specifics of male writing.

A positive feature of domestic feminist/gender criticism is the predominance of linguistic discoveries over ideology, i.e., professional, deep and reasoned analysis of linguistic texts more often pursues scientific rather than political goals. From the time of its formation, the domestic feminist critique was easily combined with other methodological strategies (often post structural, postcolonial, psychoanalytic). In the second decade of the XXIth century, gender analysis, which is formed on its achievements, is increasingly used as one of the research methods along with a wide range of others (S. Filonenko, L. Shtohman, O. Yurchuk).

Gender studies in Ukraine still consider the gender difference found in society and culture as a precedent for inequality that needs to be eliminated and, overcoming the feminist-critical strategy of 'suspicion', revise the achievements of male authors and sympathize with women's linguistic criticism. Instead, the gender approach to the analysis of linguistic research should be parity in the presentation of masculinity/ femininity in linguistics and apolitical, and therefore should reveal the difference in gender 'mentality' of the creative subject, expressed in his text/writing.
As to the classification of address by M.D. Gorodnikova, who distinguishes address-nominations, or indices, and evaluation address, or regulations (Горолникова, 2000: 120), then there is a need to indicate the following classification of address on the semantic principle:

- address-nominations of proper names and nicknames (Margaret, Stump);

- official constructions that have a connection with generally accepted norms in society (Miss Barrow, Mister Mactack);

- address that are used without mentioning the addressee (Excuse me, can you tell);

- terms of kinship, which are used in the literal and figurative sense (Mother);

- age and gender (girl, young man);

- professions (Doctor, attorney);

- status-role characteristics (office worker, mister millionaire);

- evaluative address aimed at characterization of personality (clever boy);

- substantivized adjectives (dear, sweet);

- metaphorical (angel, old bone slacker, honey, you stupid cow) (Городникова, 2000).

This analysis made it possible to identify quantitative and qualitative differences in the use of English language address - for women in the English is characterized by a reduced abundance of the use of address.

The English language is characterized by the use of proper names and official address constructions in their various combinations: Vernadette, Mrs. Dunne, Dr. Maudsley.

This focus on gender segregation in English confirms the importance of gender as the primary cultural frame for coordinating speech behaviour, which aims to establish communicative connections (Ridgeway, 2009). Traditionally, such feature of female character speech is defined as the use of neutral and affectionate treatment with a positive connotation. However, there are isolated cases of using rough, stylistically reduced units of nomination - laud bastard, boredom, scoundrel, unhappy. Such units do not necessarily indicate a negative attitude towards the recipient. An isomorphic feature of female speech behaviour with detailed address. They consist of a combination of name and attributive identifier and attachments, the purpose of which is to enhance the impact on the recipient. In addition, forms of treatment are often preceded by exclamations (Oh, my poor child).

This frequency of women's use of address as markers of rapprochement to establish and maintain contact, quite clearly confirms the theory of D. Tannen on the inherent cooperation of women's speech and communicative cooperation (Tannen, 1996: 182). 
One cannot but emphasize the pragmatic aspect, as the choice regulates the nature of interpersonal relations, and is also a means of expressing solidarity or, conversely, its absence. As well as respect or removal, respectively, a condition for successful communication (Eckert, 2003: 168).

One of the first to be criticized from the standpoint of feminist linguistics is a three-member system of addresses in English - Ms., Mrs., Miss. "Historically Mrs. and Miss were used to distinguish between female and adult females (cf. the outdated Master-Mister distinction). However, at the end of the XVIIIth century, these constructions became associated with the distinction of marital status. Critics have accused that in addition to the inherent sexism in asymmetrical treatment of men and women and labelling women as 'fit for mating' or not, the use of Miss to women over 25 has developed into an additional meaning of social unwelcome, unattractiveness' (Горошко, 2003: 50). That is why in the 40s of the XXth century, Ms. was used as a neutral alternative to women, but this treatment only began to spread in the late 1960s.

There was difficulty in choosing the right form of treatment in cases where the marital status of the addressee is unknown. It concerns both oral and written communication. Recently, the use of $M s$. no longer provokes discussion, as it is considered an acceptable innovation.

However, it should be noted that "intended to replace both Miss and Mrs., the address of Ms. began to be used (if used at all) to address only unmarried women. The only context in which it is commonly applied to all women is in business and official letters to strangers. In this way, one can avoid involuntary insults to the addressee by erroneously determining her marital status" (Bonvillain, 1997: 191).

In addition, since the biological sex is not able to explain the differences that exist in social roles and characteristics, there is a need to introduce the concept of gender.

Thus, on the one hand, gender is a mental construct or model that has been used to more adequately and correctly describe the problems associated with the article. And also to distinguish its biological and socio-cultural functions.

Ontheotherhand, genderisseenasasocial construct. Its structure includes the socially constructed roles and responsibilities of men and women, as well as their characteristics and behaviour. Such social construct is formed by society through language mechanisms.

In language, the phenomena of sexism are recorded in different ways. The main thing is gender assessment.
Thus, there are two main categories in the language -+ male (male affiliation), as well as -- male (absence of male affiliation). From this, the classification of female affiliation will be available with the sign - male. Because of this, there is a negative semantic space for the female category. The basic classification basis + masculine / - masculine, good and bad was formed. Within this limit, it is possible to interpret any expressions and concepts, and a kind of rating scale, which in turn is based on a single feature - male affiliation, which has polar values $+/$ Therefore, the gender parameter of the language personality - significantly affects the perception of the value picture of the world and, as a consequence, on verbalization in speech behaviour.

A detailed analysis of the lexicographic reflection of the gender aspect in dictionaries of different types indicates that this aspect has its irregular reflection in lexicographic sources. Comparing traditional sources and sources that make up the 'female' lexicography, it is clear that the former is characterized by ignoring the gender aspect of words. This confirms the relationship between gender changes in word semantics and the presence of sexism. A study of the definitions used in 'female' lexicography indicates that the neutral word can acquire a feminine colour. The more detailed connotations that have arisen in this case complicate the interpretation of basic and derived values. However, make it more difficult and the separate the semantic relationship between the original and derived values. The meanings recorded in lexicographic sources now change frequently as language draws attention to new communication requirements. Feminist lexicography allows not only to realize the full potential of the meaning of the word and to apply a critical attitude but also helps to consolidate gender changes in the language system.

Analyzing the ways of identifying gender assessment, there is a lack of a clear line between 'male' and 'female' axiological speech. This feature is studied as a trend of use. That is, the study of males and females should distinguish two layers of information: specific and universal. Each of them is related to the influence on the formation of speech of the following characteristics of individuals: neurophysiological, mental and other biological, as well as - with the influence of such factors as social and economic. The traditional direct dependence of the formation of male and female is age, education, upbringing, social and economic status, profession. Gender differentiation is more clearly manifested at the phonological and discursive levels, rather than at the lexical-syntactic. For example, women quite often use diminutive suffixes and diminutive-loving nominations: 'I hate her!' she 
cried desperately. Red-headed thing! Calling me 'darling' and 'honey,' and sending me handkerchiefs for C-Christmas - and then sneaking off behind closed doors and k-kissing my h-husband (Горошко, 2003: 89). Women also have a specific feature such as the use of a large number of insert words and modal constructions: "Well, you'll just have to take along what you've got. Maybe there'll be some way of getting the rest to you." "Elmers come in every week, don't they?' Daisy demanded. 'Yes, but maybe they won 't always be bringing you in.' (Eckert, 2003: 97). Women's speech is characterized by the presence of forms of politeness: "Mr Crich can't see you. He can't see you at this hour. Do you think he is your property, that you can come whenever you like?" (Ridgeway, 2009: 288-289).

As well as the lack of such a feature as dominance, i.e., they listen more and focus on the problematic aspects of the conversation with the interlocutor. More precisely, women's speech is humane and mostly non-aggressive. Women are usually compliant and unsure of controversy, so they will more often refer to specific cases from personal experience. Unlike men, whose speech is rude and with frequent use of obscene words: "Go to hell ... Do you think I can make an actress of you in a season? Do you think I'm going to work my guts out to make you give a few decent performances and then have you go away to play some twopenny-halfpenny part in a commercial play in London? What sort of a bloody fool do you take me for? .." (Tannen, 1996). They most often choose active verbs: "I don't care, 'said George. 'I'll give you twenty-four hours to decide.' (Ridgeway, 2009: 162). It should not be overlooked that the dialogues of men and women are characterized by the interruption of interlocutors. Men are less likely to do this to a woman, but when talking to a man, a sign of interruption is often present in such a dialogue.

It should be noted that the models of expression of one's opinion are inherent in women's speech. Often women's speech is coloured by a positive assessment, while men are characterized by rational over-emotional. They choose accuracy, the tendency to use expressive and stylistically reduced means.

Conclusions and further research prospects. This study confirmed that gender transformations in different countries of the world contribute to the recognition and growing interest in the development of gender-sensitive national languages.

The study found that the growing scientific interest in gender issues has led to the formation of a special linguistic field - gender linguistics, which aims to study the features of male and female speech, due to both psychological and behavioral differences between the sexes and social factors.

As for the address, it is a word or combination of words that names those to whom the communicator addresses. address-indexes name a person and express the social status of the interlocutor: position; occupation; academic degree; rank; rank; title.

Regulatory address are evaluative and regulate the relationship between interlocutors following speech and etiquette standards and norms common in a particular society. Without entering into syntactic connections with other words in the sentence, the address has a special intonation and a special communicative purpose - to control the behaviour of the recipient. address create a transition between identifying and predicative nominations, a transition from objective semantics to subjective semantics. Depending on the gender characteristics of the participants of communication, the situation of communication and the intention of the addressee in the messages are dominated by elements of encouraging, contact, metacommunicative or evaluative-modal speech actions. When choosing an address in a particular speech act, the characteristics of the addressee are differentiated at the basic level of categorization: acquaintance-stranger, man-woman, senior-junior-equal, socially higher-lower-equal, and so on. In the etiquette of business communication, this differentiation usually has clear linguistic equivalents.

Summing up, it is worth mentioning the gender features of the use of address in English, which include address-nominations proper names, nicknames; official circulating constructions related to generally accepted norms in society; treatment without mentioning the addressee; terms of kinship in the literal and figurative sense; age, sex; profession; status and role characteristics; evaluative address of personality characteristics; substantivized adjectives; metaphorical.

\section{BIBLIOGRAPHY}

1. Байбурин А. К. Этнические стереотипы поведения. Львів : Наука, 1985. 330 с.

2. Бацевич Ф. С. Основи комунікативної лінгвістики. Київ : Видавничий центр «Академія», 2004. 344 с.

3. Брандт Г. А. Философская антропология феминизма. Природа женщины : монография. Санкт-Петербург, 2006. $160 \mathrm{c}$

4. Городникова М. Д. Гендерний аспект обращения как фактор речевого регулирования. Москва : Рудомино, 2000. C. $118-125$.

5. Горошко Е. И. Языковое сознание: гендерная парадигма. Харьков : ИНЖЭК, 2003. 440 с. 
6. Халеева И. И. Гендер как интрига познания. Москва : Рудомино, 2000. С. 9-14.

7. Bonvillain N. Language, culture, and communication: the meaning of messages. 1997. 374 p.

8. Eckert P. Language and Gender. Cambridge : Cambridge University Press, 2003. 366 p.

9. Ehrhardt A. John Money, Ph. D. The Journal of Sex Research, 44:3, 2007.P. 223-224.URL: https://www.tandfonline.com/ doi/abs/10.1080/00224490701580741.

10. Herbert Robert K., Nykiel-Herbert Barbara. Explorations in Linguistic Sexism: a Contrastive Sketch II, Papers and Studies in Contrastive Linguistics, V. 21. 1986. P. 47-85.

11. Money J., Hermaphroditism, gender and precocity in hyperadrenocorticism: psychologic findings. Bull Johns Hopkins Hosp, 1955, jun, 96(6). P. 253-264.

12. Ridgeway C. L. Framed before we know it: How gender shapes social relations. Gender \& Society: Official Publication of Sociologists for Women in Society, 23(2), 2009. P. 145-160.

13. Scott J. Only Paradoxes to Offer: French Feminists and the Rights of Man. Cambridge. 1996.

14. Stoller R. Sex and Gender: On the Development of Masculinity and Femininity, Science House, 1968. 383 p.

15. Tannen D. Gender and Discourse. New York : Oxford University Press, 1996. 221 p.

\section{REFERENCES}

1. Baiburin A.K. Etnicheskie stereopipy povedeniya. [Ethnic stereotypes of behaviour]. Lviv: Nauka, 1985.330 p. [in Russian].

2. Bacevych F.S. Osnovy komunikatyvnoi lingvistyky. [The essence of communicative linguistics]. Kyiv: vydavnychyi centr "Academia", 2004. 344 p. [in Russian].

3. Brandt H.A. Philosophskaya antropologiya feminizma. Priroda zhensvhiny: monographiya. St. Peterburg, 2006.160 p. [in Russian].

4. Gorodnicova M.D. Gendernyi aspect obrascheniya kak factor rechevogo regulirovaniya. Moskva: Rudomino, 2000. P. 118-125. [in Russian].

5. Goroshko E.I. Yazykovoe soznaniye: gendernaya paradigma. Kharkov: Izdatelskyi dom "INZHEK”, 2003.440 p. [in Russian].

6. Khaleeva I.I. Gender kak intriga poznaniya. Moskva: Rudomino, 2000. P. 9-14. [in Russian].

7. Bonvillain N. Language, culture, and communication: the meaning of messages. 1997. 374 p. [in English].

8. Eckert P. Language and Gender. Cambridge: Cambridge University Press, 2003. 366 p. [in English].

9. Ehrhardt A. John Money, Ph. D. The Journal of Sex Research, 44:3, 2007. P. 223-224. URL: https://www.tandfonline. com/doi/abs/10.1080/00224490701580741 [in English].

10. Herbert Robert K., Nykiel-Herbert Barbara. Explorations in Linguistic Sexism: a Contrastive Sketch II, Papers and Studies in Contrastive Linguistics, V. 21 1986. P. 47-85. [in English].

11. Money J., Hermaphroditism, gender and precocity in hyperadrenocorticism: psychologic findings. Bull Johns Hopkins Hosp, 1955, jun, 96(6), P. 253-264. [in English].

12. Ridgeway C. L. Framed before we know it: How gender shapes social relations. Gender \& Society: Official Publication of Sociologists for Women in Society, 23(2), 2009. P. 145-160. [in English].

13. Scott J. Only Paradoxes to Offer: French Feminists and the Rights of Man. Cambridge. 1996. [in English].

14. Stoller R. Sex and Gender: On the Development of Masculinity and Femininity. Science House, 1968.383 p. [in English].

15. Tannen D. Gender and Discourse. New York: Oxford University Press, 1996. 221 p. [in English]. 